\title{
Industry expectations of supply chain management graduates: Perspectives from third-party logistics providers in South Africa
}

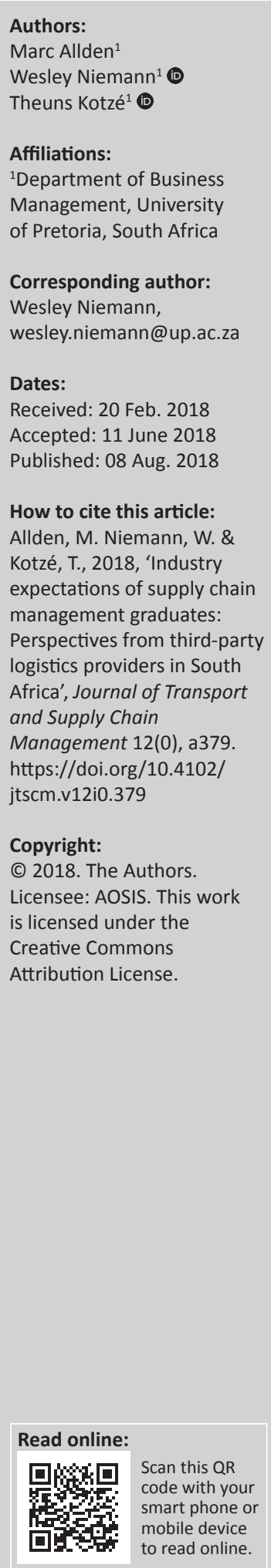

Background: There is currently a skills mismatch between what the third-party logistics (3PL) industry expects from new supply chain management graduates and what the educational system supplies. As the traditional roles of 3PLs are changing, subsequently increasing their importance within the supply chain industry, supplying graduates with the necessary skills becomes even more critical.

Objectives: The aim of this study was to determine what the South African 3PL industry expects from new graduates with a bachelor's degree in supply chain management or related fields in relation to skills, personal attributes and knowledge.

Method: A generic qualitative research design was used to collect data from 12 participants using semi-structured interviews.

Results: It was found that academic institutions equip new graduates adequately with knowledge, but not with the expected skills. Furthermore, the findings confirmed the current literature, while also identifying additional expectations. 3PLs expect new graduates to perform various activities throughout the supply chain, such as warehousing and transport activities, while simultaneously using their technological knowledge and abilities to improve different processes within the supply chain. This requires new graduates to be creative, innovative and analytical and to have advanced communication skills. Therefore, supply chain management programmes should provide graduates with more exposure and experiences in real-life supply chain settings.

Conclusion: The findings allow for academic institutions to revise and adapt their curricula to meet the need of more practical skills development.

\section{Introduction}

Conflict emerges when new graduates are confronted with the reality of what the industry expects from them (Jusoh, Simun \& Choy Chong 2011:516). The mismatch between graduates and industry expectations has been placed under the microscope, especially in South Africa, as skills mismatch contributes to rising levels of unemployment among youth in the country (Reddy et al. 2016:86; Van Broekhuizen 2016:1). This is also true for the third-party logistics (3PL) provider industry in South Africa (Havenga et al. 2016:13; Langley 2016:4). While industry expectations of experienced South African supply chain practitioners' skills, knowledge and competencies seem to be known (Heyns \& Luke 2012:117), the same cannot be said for new graduates with a bachelor's degree in supply chain management, logistics, operations management or procurement. Uncertainty concerning the industry's expectations of these graduates' skills, knowledge and competencies remains (Christine \& Ozlem 2016:611; Elzarka \& El-Nakib 2014:8).

Curkovic and Fernandez (2016:697), Elzarka and El-Nakib (2014:3) and Sohal (2013:438-439) focused on determining the skills, knowledge and personal attributes expected from supply chain graduates in the United States of America (USA), Egypt and Australia, respectively. The identified skills include the ability to work in teams, solving problems and possessing analytical and communication skills, whereas personal attributes include graduates being creative, having interpersonal skills and the ability to manage time. Knowledge expected of graduates includes knowledge about logistics and transportation management, current developments in the supply chain industry and supply chain sustainability.

A review of the literature clearly suggests that there is a mismatch between what employers expect from graduates and what is provided by university education (Barloworld Logistics 2016a:2; Langley 2016:4). Reddy et al. (2016:8) identified this as an educational supply mismatch, 
where educational institutions do not provide the industry with graduates who possess the requisite skills. This mismatch thus creates a skills shortage, which is being experienced in various countries including the United Kingdom (UK), Australia and the USA (Curkovic \& Fernandez 2016:698). Research shows that academics focus on skills such as purchasing, organising, inventory control and time management, whereas the industry's main concerns include planning, customer service, warehousing and marketing (Cevik Onar et al. 2013:399; Elzarka \& El-Nakib 2014:6-8). The skills mismatch is also evident in the South African supply chain industry, leading to a skills shortage, as in the case of the UK, Australia and USA (Heyns \& Luke 2012:120; Nzimande 2016:6; TETA 2017:3-5). To address this supply chain skills mismatch and the resulting skills shortage, the alignment of higher education outcomes with the needs of the industry is emphasised (Chetty 2012:19; Fraser 2013:55; Havenga et al. 2016:13). To assist with this alignment, the industry's expectations of new graduates with a bachelor's degree in supply chain management or related fields must be determined. However, a review of the literature reveals that there is a lack of academic knowledge with a focus on the skills, personal attributes and knowledge expected of such graduates.

The purpose of this generic qualitative study is thus to determine South African 3PLs' expectations of new graduates with a bachelor's degree in supply chain management or related fields, who enter the workforce for the first time. More specifically, the study aims to determine the necessary skills, personal attributes and specific knowledge that these new graduates must have in order to excel in the workplace.

Against this background, the following research questions guided the study:

- What are the necessary skills that employers expect graduates with a supply chain management qualification to possess?

- What are the personal attributes that employers expect from graduates with a supply chain management qualification?

- What specific knowledge do employers expect graduates with a supply chain management qualification to possess?

This study contributes to the current body of knowledge on employers' expectations of supply chain graduates by determining which skills, personal attributes and knowledge graduates with supply chain management or related qualifications need within the 3PL industry of South Africa. 3PLs expect new graduates to perform various activities throughout the supply chain such as warehousing and transport activities, while simultaneously using their technological knowledge and abilities to improve different processes within the supply chain. This requires new graduates to be creative, innovative, analytical and to have advanced communication skills. In the international context, it confirms what is currently known on this topic. The findings also allow South African academic institutions to adapt and improve their current supply chain management curricula to better inform graduates on what is required of them in the work environment. Ultimately, students will be able to better prepare themselves for a supply chain management career by knowing which skills, personal attributes and knowledge they need to develop.

The remainder of this article is structured as follows: firstly, industry expectations of supply chain graduates in other parts of the world are discussed. The research design, strategy and methods used in the study are described next, after which the research findings are presented and discussed in light of the literature reviewed. Finally, the theoretical and managerial contributions of this study, as well as its limitations and future research opportunities, are discussed.

\section{Literature review}

\section{The South African supply chain and third-party logistics industry}

The supply chain industry plays a significant role in South Africa, given that the total logistics costs of R499 billion contribute $11.8 \%$ of the total South African GDP (Havenga et al. 2016:3). To battle rising costs, firms increasingly turn to 3PLs (Bloem \& Bean 2015:2; Karrapan et al. 2017:2). Vitasek (2013:195) defines a 3PL as 'a firm that provides multiple logistics services for use by customers', whereas Hwang, Chen and Lin (2016:105) define a 3PL as a firm 'that performs logistics functions that would once have been performed by either the shipper or the recipient'. For the purpose of this study, the definition of Akman and Baynal (2014:3) is used, which defines 3PLs as 'external suppliers that fulfil a portion or all of a company's logistics functions'.

The role of 3PLs has changed over time (Langley 2016:49). Not only do they now provide cost reductions for firms (Bloem \& Bean 2015:2) but they also serve as supply chain transformation agents, integrating the different parts of the organisation's total supply chain and ultimately creating better supply chain efficiencies for their customers (Langley 2017:24; Meyer, Niemann \& Kotzé 2017:2). This creates a heightened need for the correct skills; however, within the South African supply chain industry, there currently exist skills shortages and mismatches between the supply and demand of these skills (Barloworld Logistics 2016a:28; Heyns \& Luke 2012:111; TETA 2017:3-5). The mismatch between the required and supplied skills can be attributed to three sources (Reddy et al. 2016):

- Demand mismatches - this mismatch is determined by new types of jobs created.

- Educational supply mismatches - this mismatch is caused by educational institutions not providing graduates with the skills demanded by industries.

- Qualification mismatches - this mismatch occurs when people are appointed in a related field and not to the specific field in which they have a qualification. (p. 74)

A major contributor to the skills shortage and mismatch is the low level of education in South Africa, not providing 
the industry with enough suitably qualified graduates (Modisaotsile 2012:1; Reddy et al. 2016:86). The importance of education to battle this shortage is also highlighted by Barloworld Logistics (2016b:52) and Heyns and Luke (2012:121).

\section{Expectations regarding general employability skills}

Increasingly, more emphasis is placed on graduates with the skills needed to be seen as employable to prospective employers (Aida, Norailis \& Rozaini 2015:768). Ju, Zhang and Pacha (2011:30) label these skills as 'employability skills', which they define as the 'general skills needed from employees without regard to a specific industry or job position'.

Lowden et al. (2011:1), Ju et al. (2011:30) and Aida et al. (2015:767) all focused on identifying these employability skills required from new graduates in the UK, USA and Malaysia, respectively. These studies involved multiple industries, and thus the identified skills are categorised as generic skills.

There are commonalities regarding the skills required by new graduates in the studies by Lowden et al. (2011:12), Ju et al. (2011:33) and Aida et al. (2015:768). The repetitive identification of the following skills in different contexts highlights their importance to employers:

- making decisions and solving problems

- thinking in a critical and creative manner

- being able to communicate effectively with others

- the ability to negotiate with other individuals

- being able to function in teams

- the ability to work with individuals from diverse backgrounds

- being able to read and write

- basic math skills.

Ju et al. (2011:33) state that new graduates must have various personal attributes in addition to these skills in order to make them attractive as employees (Aida et al. 2015:768). These personal attributes include graduates being honest and having integrity, being responsible individuals, being adaptable to change, being punctual, having respect for others and maintaining appropriate personal appearances. Lowden et al. (2011:12) and Aida et al. (2015:768) mention that graduates must also have the knowledge of computers and technologies. However, the knowledge that new graduates must possess is often industry-specific, and this will be covered in more detail in the next section.

\section{Supply chain industry-specific skills}

Different studies use the terms 'competencies' or 'skills' to describe the abilities needed by practitioners or graduates and thus these two terms will be used interchangeably, depending on the specific study being discussed. For the purpose of this study, skills and competencies refer to the ability needed by new graduates to be able to perform certain activities (Oxford 2017). Personal attributes can be seen as a quality or trait of new graduates, while knowledge refers to a theoretical understanding obtained through education (Oxford 2017).

\section{Industry expectations of current supply chain professionals}

To determine the competencies that supply chain managers need, studies by American Production and Inventory Control Society (APICS 2014:4), Cilliers (2015:4) and Heyns and Luke (2012:113) were analysed. The APICS model lists the competencies as determined by the leading international professional associations for supply chain management, while Cilliers (2015:4) and Heyns and Luke (2012:113) list the skills expectations in a South African supply chain industry.

APICS developed a supply chain manager competency model that comprises three competency categories and six competency tiers (APICS 2014:4; Vokurka 2011:26-27). The model follows a bottom-up approach and starts with basic personal effectiveness competencies and culminates in a set of requirements specific to materials managers.

Cilliers (2015:192) also developed a supply chain competency model. However, the focus was on the South African supply chain industry, differing from the US focus of the APICS competency model, whereas Heyns and Luke (2012:113) set out to only determine industry expectations and not to create a specific model.

From an analysis of the studies by APICS (2014:4), Cilliers (2015:4) and Heyns and Luke (2012:113), it is clear that supply chain practitioners must possess certain personal attributes in order to make them effective in the industry. These attributes include being able to communicate effectively, demonstrating creativity, having integrity, being able to motivate and negotiate with others, working in teams and managing time effectively (APICS 2014:5-6; Heyns \& Luke 2012:113).

It is also important for the practitioners to have a theoretical understanding of supply chain management, which includes various aspects like knowledge of their industry, knowledge of cost drivers in the supply chains, the terminology used, the different processes in firms and the different elements that make up the supply chain (APICS 2014:4; Cilliers 2015:194; Heyns \& Luke 2012:113). Heyns and Luke (2012:117) and Cilliers (2015:194) state that general business management skills such as making decisions, solving problems, being able to plan, leading others, project management, conflict management and managing change are also important skills that supply chain practitioners must possess.

All three studies mentioned above identified very specific supply chain-related skills, including forecasting demand, balancing supply and demand, designing a logistics network, developing logistics strategies, managing the procurement process and order processing, managing warehouse activities (such as designing and optimising warehouse layouts, receiving, putting away, managing inventory and picking), 
managing transportation and distribution (including fleet management, routing and scheduling of deliveries), ensuring compliance to regulations impacting firms, and understanding and implementing supply chain concepts (such as lean supply chain, Six sigma and Just-in-Time) (APICS 2014:4; Cilliers 2015:192-193; Heyns \& Luke 2012:117).

There are also certain skills that are growing in importance in the supply chain industry. These include the ability of practitioners to understand and implement technology in the supply chain in order to improve processes and manage the supply chain in a sustainable and environmentally friendly manner (APICS 2014:10; Cilliers 2015:194; Heyns \& Luke 2012:117).

Furthermore, the APICS supply chain competency model adds an extra category, differentiating its model from that of Cilliers (2015:4) and Heyns and Luke (2012:117). This category, materials managers' specific requirements, includes requirements like certification, licensure, specialised educational degrees or physical and training requirements for supply chain managers (APICS 2014:4).

It is thus evident that there are clear expectations from the industry of current supply chain practitioners, especially in South Africa. However, as previously mentioned, the same cannot be said for new graduates with a bachelor's degree in supply chain management, logistics, operations management or procurement.

\section{Industry expectations of new supply chain graduates}

Because of the lack of literature on South African industry expectations of new supply chain graduates, the focus is on international studies which will serve as a frame of reference for what is expected of new supply chain graduates. Curkovic and Fernandez (2016:699), Elzarka and El-Nakib (2014:3) and Sohal (2013:438) all focused on determining what the supply chain industry expects from new graduates with a bachelor's degree in supply chain management, logistics, operations management, procurement or related fields in the USA, Egypt and Australia, respectively. Each study followed a different approach to reporting the findings, either providing a list or categorising the identified expectations.

Curkovic and Fernandez (2016:699) identified three skills that are most important to US employers with respect to new graduates. These skills are as follows: (1) graduates need to be conscious of the business environment they enter, with regard to new developments in science and technology; (2) they must be able to work in teams and with people of diverse backgrounds; and (3) they must be capable to apply their skills to solving real-world problems. Other graduate skills that employers regard as important include leadership abilities, the ability to communicate orally and in writing, analytical skills, being able to work with computers and technology, being adaptable, interpersonal skills, being able to plan strategically and being creative (Curkovic \& Fernandez 2016:699).
Elzarka and El-Nakib (2014:6), in turn, focused on skills expectations within the BLM Framework created by Murphy and Poist (2006:46), which skills into business, logistics and management skills categories. The expected skills identified in this study are summarised in Table 1.

Lastly, Sohal (2013:438) identified both generic and supply chain-specific skills that the Australian supply chain industry expects of new graduates. These skills were grouped together in the so-called supply chain management graduate requirement matrix (Sohal 2013:430). The skills in this matrix are listed in Table 2.

The findings of the aforementioned studies can be consolidated to provide a simple and clearer picture of what the industry expects from new graduates in terms of skills, knowledge and personal attributes (see Table 3).

TABLE 1: Business, logistics and management skills expected from supply chain graduates.

\begin{tabular}{|c|c|}
\hline Skill & Description \\
\hline Business & $\begin{array}{l}\text { - Transportation and logistics. } \\
\text { - Marketing. } \\
\text { - Strategic management. } \\
\text { - Foreign languages. } \\
\text { - Procurement. }\end{array}$ \\
\hline Logistics & $\begin{array}{l}\text { - Customer service. } \\
\text { - Warehousing. } \\
\text { - Return goods handling. } \\
\text { - Distribution communications. } \\
\text { - International logistics. } \\
\text { - Traffic/Transport management. } \\
\text { - Demand forecasting. }\end{array}$ \\
\hline Management & $\begin{array}{l}\text { - Planning. } \\
\text { - } \text { Organising. } \\
\text { - Managing time. } \\
\text { - Heing able to motivate people. } \\
\text { - Being the ability to negotiate. } \\
\text { - Must be able to train subordinates if need be. } \\
\text { - Being able to supervise others. } \\
\text { - Analytical reasoning. } \\
\text { - Being able to listen intently. } \\
\text { - Having an outgoing personality. }\end{array}$ \\
\hline
\end{tabular}

Source: Elzarka, S. \& El-Nakib, l., 2014, 'Skills requirements for entry-level logisticians: An empirical study of academics and practitioners perception in Egypt', Paper presented at the 19th Logistics Research Network Conference, University of Huddersfield, UK, 3-5 September, pp. 1-9, viewed 11 March 2017, from https://www.researchgate.net/profile/Islam_El-Nakib/ publication/280730321_SKILLS_REQUIREMENTS_FOR_ENTRY_LEVEL_LOGISTICIANS_AN EMPIRICAL_STUDY_OF_ACADEMICS_AND_PRACTITIONERS_PERCEPTION_IN_EGYPT/ links/55c3681d08aebc967df0f2ad.pdf

TABLE 2: The skills expectations as set out in the supply chain management graduate requirement matrix.

\begin{tabular}{ll}
\hline Skill & Description \\
\hline Generic & - Being able to communicate effectively. \\
& - Being socially active and able to manage relationships. \\
& - Being proficient with technologies. \\
- Analysing relevant information and solving problems. & Being able to work with and manage finances and budgets. \\
- Having a continuous improvement mindset. & Being able to manage projects. \\
& - Being able to manage diversity and change. \\
- Graduates possessing comprehensive knowledge of supply \\
chain-specific \\
- Main management. \\
- Must be able to apply strategic thinking to supply chain \\
- An understanding of how supply chain management \\
interconnects with other functions of the business. \\
- Having both a local and a global understanding of supply \\
chain and logistics management. \\
- Possessing knowledge of supply chain and sustainability. \\
temonstrating knowledge of supply chain-related \\
technologies.
\end{tabular}

Source: Sohal, A.S., 2013, 'Developing competencies of supply chain professionals in Australia: Collaboration between businesses, universities and industry associations', Supply Chain Management: An International Journal 18(4), 429-439 
TABLE 3: Consolidated list of international industry expectations of new supply chain graduates.

\begin{tabular}{|c|c|}
\hline Variable & Industry expectation \\
\hline Skills & $\begin{array}{l}\text { - Solving problems. } \\
\text { - Be proficient in using technology. } \\
\text { - Mble to plan strategically. } \\
\text { - Manage transportation. } \\
\text { - Manage warehousing activities. } \\
\text { - Must be able to provide customer service. } \\
\text { - Perform reverse logistics. } \\
\text { - Be able to plan. } \\
\text { - Be able to organise various activities. } \\
\text { - Must be able to manage projects. }\end{array}$ \\
\hline $\begin{array}{l}\text { Personal } \\
\text { attributes }\end{array}$ & $\begin{array}{l}\text { - Able to work in teams. } \\
\text { - } \text { Leadership abilities. } \\
\text { - Analytical thinker. } \\
\text { - Adaptable. } \\
\text { - Must have interpersonal skills. } \\
\text { - Must be creative. } \\
\text { - Must be able to motivate others. } \\
\text { Must be able to negotiate. }\end{array}$ \\
\hline Knowledge & $\begin{array}{l}\text { - Industry-specific knowledge. } \\
\text { - Must possess knowledge of foreign language. } \\
\text { - Understand financial implications of supply chain activities. } \\
\text { - Understand how different business units integrate with each other. } \\
\text { - Knowledge of supply chain-related technology. } \\
\text { - Knowledge of sustainable supply chain operations. }\end{array}$ \\
\hline
\end{tabular}

In comparing this consolidated list with what is expected from current industry practitioners in South Africa (Curkovic \& Fernandez 2016:699; Elzarka \& El-Nakib 2014:3; Sohal 2013:430), it can clearly be stated that there is a strong alignment between what is expected from new graduates and current practitioners. Although all the skills, personal attributes and knowledge areas listed in Table 3 are part of the South African industry expectations for current practitioners, it must be asked if the South African industry expects the same of new supply chain graduates.

\section{Methodology Research design}

An empirical, generic qualitative research design was used to collect data with the aim of answering specific questions about the industry's expectations of new supply chain graduates (Jasti \& Kodali 2014:1081). This design allowed for the creation of an in-depth understanding of what the South African 3PL industry expects from new graduates. It also allowed for the use of semi-structured interviews to gather primary data from participants with the necessary knowledge of what the industry expects from new graduates (Cooper \& Endacott 2007:817; Lambert \& Lambert 2012:256). Plano Clark and Creswell (2015:289) support the chosen design as they believe that it will enable the researcher to develop a detailed, information-rich description of what is expected of new graduates.

\section{Selection of participants}

The units of analysis were managers of firms in the South African 3PL industry, with the necessary knowledge of what is expected of new graduates. Purposive sampling strategies were used to select firms and participants (Palinkas et al. 2015:534). Firms were selected using homogeneous sampling, which allowed the researcher to understand what the specific industry expects from new graduates (Creswell 2012:208).
The participants were selected using criterion sampling, which required them to meet the following criteria (Polit \& Beck 2012:519): they had to be directly involved in selecting or working with new graduates or had to take part in developing the graduate programme where applicable. Table 4 provides the profile of the participants.

A total of 12 firms and 15 participants took part in the study. One person was interviewed per organisation, except for O1 where three individuals were interviewed. Multiple participants were interviewed in $\mathrm{O} 1$ as $\mathrm{P} 1$ believed the knowledge of her training team would be beneficial to the study. The sample size was determined by data saturation, which occurred in the 10th interview, after which three more interviews were conducted. This sample size aligns with the principle of Francis et al. (2010:1242), who found that data saturation tends to occur from the 10th interview onwards.

\section{Data collection}

Thirteen semi-structured interviews were conducted between August and October 2017 to collect the necessary data. Of the 13 interviews, 12 were conducted with one participant, whereas P1, P2 and P3 were all interviewed together. Eleven interviews were conducted at the offices of the participants, whereas participants P5 and P15 were interviewed by telephone and P6 by video call. The use of semi-structured interviews allowed the researcher to perform the interviews through various media, and allowed participants to provide in-depth information on what is expected from new graduates, unconstrained by any previous perspectives of the researcher (Creswell 2012:218; Hamilton 2014:353). Only 12 of the 13 participants provided adequate information and the unsatisfactory data collected from P12 were discarded as he did not meet the necessary participant inclusion criteria.

A discussion guide was created by an iterative process of development and evaluation based on the literature reviewed. A pilot test was conducted with the training and development manager, coordinator and trainer of a South African 3PL, after which only minor changes were made to this guide. Making only minor changes allowed the researcher to use the obtained information during presentation of the findings.

The participants were contacted by telephone or through email to arrange meetings. During the interview, the participants were provided with and signed the informed consent form and gave permission to record the interviews. Only P1, P2 and P3 denied permission to record, and thus extensive field notes were made during these particular interviews. Interviews ranged from $20 \mathrm{~min}$ to $52 \mathrm{~min}$, with an average length of $36 \mathrm{~min}$. Transcriptions of interviews were done through a professional transcription service. The transcripts were checked for quality by means of the researcher listening to the recordings while simultaneously reading through the transcription and making amendments if necessary. 


\begin{tabular}{|c|c|c|c|c|}
\hline Participant ID & Job title & Organisation ID & Gender & $\begin{array}{l}\text { Interview duration } \\
\text { (minutes) }\end{array}$ \\
\hline P1 & Training and development manager & 01 & Female & 36 \\
\hline P2 & Training and development coordinator & 01 & Female & 36 \\
\hline P3 & Training and development trainer & 01 & Female & 36 \\
\hline P4 & Supply chain specialist & $\mathrm{O} 2$ & Male & 21 \\
\hline P5 & Warehouse coordinator & $\mathrm{O} 3$ & Male & 24 \\
\hline P6 & Western Cape regional manager & $\mathrm{O} 4$ & Male & 34 \\
\hline P7 & Supply chain solutions manager & 05 & Male & 46 \\
\hline P8 & Supply chain solutions manager & O6 & Male & 49 \\
\hline P9 & Operations manager & 07 & Male & 45 \\
\hline P10 & Executive: Business development and sales & 08 & Male & 25 \\
\hline P11 & Divisional director (Strategic projects, BCM and QSHE) & 09 & Male & 52 \\
\hline P13 & Business development director & 011 & Male & 29 \\
\hline P14 & Senior HR business partner & $\mathrm{O} 10$ & Male & 48 \\
\hline
\end{tabular}

P, participant; O, organisation; BCM, business continuity manager; QSHE, quality, safety, health and environment; HR, human resources.

\section{Data analysis}

Thematic analysis was used to identify, analyse and finally report on patterns and key topics in the collected data (Vaismoradi, Turunen \& Bondas 2013:78). The researcher familiarised himself with the data by reading the transcripts and simultaneously listening to the recordings. During data analysis, inductive codes were generated from the data and were combined with deductive codes found (Clarke \& Braun 2013:122). Themes were identified from the codes and a code list was generated. Codes and themes were constantly revised, amended when necessary, and finally aligned with the research questions (Clarke \& Braun 2013:122).

\section{Trustworthiness}

Dependability and transferability were obtained by providing detailed descriptions of the specific methods followed (Polit \& Beck 2012:585). This included descriptions of the research design, context of the study, sampling methods used (as well as providing inclusion criteria for participants), data collection and analysis methods, and finally the limitations of the study with directions for future research. Confirmability was obtained through asking open-ended questions, ensuring accuracy of the transcriptions and providing appropriate quotations to substantiate the findings (Polit \& Beck 2012:585; Shenton 2004:72).

\section{Ethical consideration}

This study was approved by the research ethics committee of a South African university prior to data collection. All participants gave voluntary consent to be interviewed and signed an informed consent form. The researchers assured the participants before the start of each interview that anonymity and confidentiality would be practised. The researchers also reminded the participants that they could withdraw from the interview at any time.

\section{Findings}

This study identified the expectations of 3PLs concerning the skills, personal attributes and knowledge that new supply chain graduates must possess. These three elements constitute the themes of the study, which helps the researcher answer each of the stated research questions. The identified themes and their relationship with the research questions are listed in Figure 1.

The following sections discuss each of the identified themes and highlight the most important expectations of each theme as mentioned by the participants. It is important to note that skills identified by P1, P2 and P3 will be merged together as they all work at $\mathrm{O} 1$.

\section{Findings related to skills}

During the study, the participants emphasised their key services provided, which include warehousing and transportation. They consequently emphasised the skills expected from graduates concerning the warehouse and transportation management activities. Other, more general, supply chain skills were also mentioned that do not form part of either warehouse or transportation skills. These three skills categories are explained in the sections that follow.

\section{Warehouse management}

The skills identified by the participants concerning warehouse management are presented in Table 5 .

By combining the results of the top three warehouse management skills in Figure 1, it can be seen that a total of 11 participants stated that their organisation requires new graduates to actively take part in the different warehousing activities. This requires new graduates to firstly receive goods, including the offloading of goods delivered to the organisation's warehouse. Active participation is shown in the following quotation:

'They literally started putting me into, into the cages where I started offloading tyres and, and stuff like that, which is not the best but, you know, it's all part of the learning.' (P5, male, warehouse coordinator)

Once new graduates can perform receiving activities satisfactorily, they are then required to manage inventory. 


\begin{tabular}{|c|c|c|c|}
\hline Research question & $\begin{array}{l}\text { What were the necessary skills that employers } \\
\text { expected graduates with a supply chain } \\
\text { management qualification to possess? }\end{array}$ & $\begin{array}{l}\text { What were the personal attributes that } \\
\text { employers expected from graduates with a } \\
\text { supply chain management qualification? }\end{array}$ & $\begin{array}{l}\text { What specific knowledge did employers expect } \\
\text { graduates with a supply chain management } \\
\text { qualification to possess? }\end{array}$ \\
\hline $\begin{array}{l}\text { Theme } \\
\text { Sub-theme }\end{array}$ & 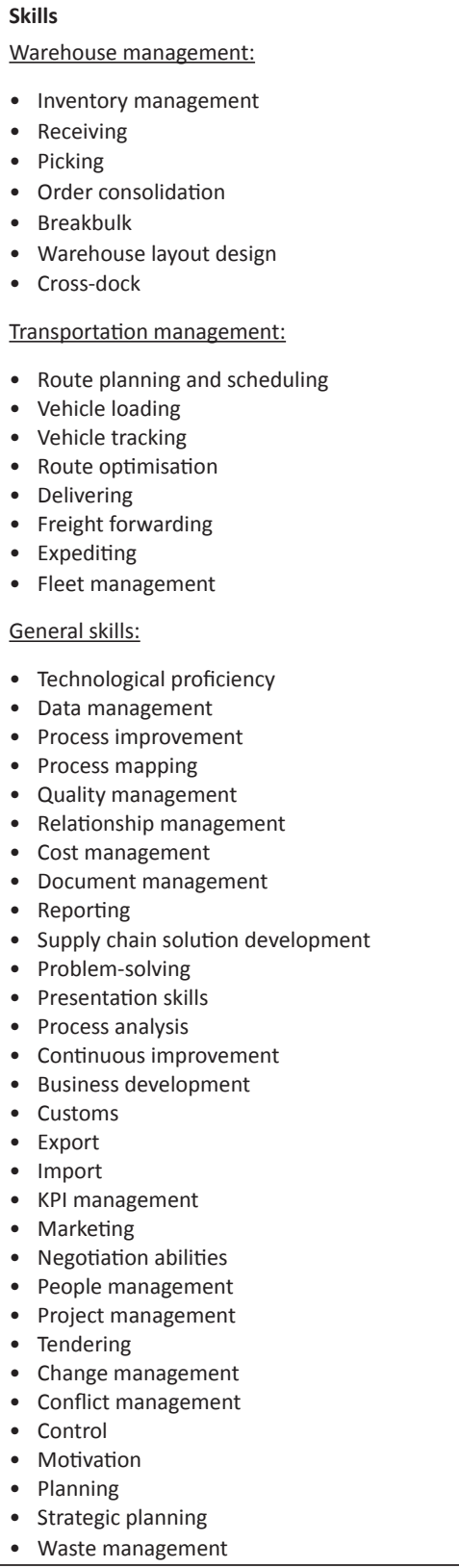 & $\begin{array}{l}\text { Personal attributes } \\
\text { - Communication } \\
\text { - Hardworking } \\
\text { - Right mentality } \\
\text { - Analytical } \\
\text { - Continuous learning } \\
\text { - Innovative } \\
\text { - Integrity } \\
\text { - Adaptable } \\
\text { - Confidence } \\
\text { - Critical thinking } \\
\text { - Culture fit } \\
\text { - Passion } \\
\text { - Self-management } \\
\text { - Creative } \\
\text { - Extrovert } \\
\text { - Leadership abilities } \\
\text { - Respect } \\
\text { - Teamwork } \\
\text { - Diversity management } \\
\text { - Trust }\end{array}$ & $\begin{array}{l}\text { Knowledge } \\
\text { - Technology } \\
\text { - Comprehensive supply chain knowledge } \\
\text { - Financial knowledge } \\
\text { - Terminology } \\
\text { - Business integration } \\
\text { - Business understanding } \\
\text { - Equipment } \\
\text { - Industry knowledge } \\
\text { - Product-specific knowledge } \\
\text { - Supply chain integration } \\
\text { - Laws and regulations } \\
\text { - SHEQ } \\
\text { - Labour legislation }\end{array}$ \\
\hline
\end{tabular}

$\mathrm{KPI}$, key performance indicators; SHEQ, safety, health, environment and quality.

FIGURE 1: A summary of research questions and their related themes.

TABLE 5: The industry's expectations concerning warehouse management skills.

\begin{tabular}{|c|c|c|c|c|c|c|c|c|c|c|c|c|c|}
\hline \multirow[t]{2}{*}{ Skills } & \multicolumn{12}{|c|}{ Participants } & \multirow[t]{2}{*}{ Total } \\
\hline & P1, P2, P3 & P4 & P5 & P6 & P7 & P8 & P9 & P10 & P11 & P13 & P14 & P15 & \\
\hline Inventory management & $x$ & - & - & $x$ & $x$ & $x$ & $x$ & $x$ & $x$ & $x$ & $x$ & - & 9 \\
\hline Receiving & $x$ & - & $x$ & $x$ & - & $x$ & $x$ & - & - & - & $x$ & $x$ & 7 \\
\hline Picking & $\mathrm{x}$ & - & - & - & - & $x$ & $x$ & - & $x$ & - & $x$ & $x$ & 6 \\
\hline Order consolidation & - & - & $x$ & - & - & - & $x$ & - & $x$ & - & $x$ & - & 4 \\
\hline Break-bulk & $x$ & - & - & $\mathrm{x}$ & - & - & - & - & $x$ & - & - & - & 3 \\
\hline Cross-dock & - & - & - & - & - & - & - & - & $x$ & - & - & - & 1 \\
\hline
\end{tabular}

$\mathrm{P}$, participant; $\mathrm{X}$, indicator.

Managing inventory requires new graduates to be able to determine the necessary stock levels within the warehouse, the locations for different goods, perform cycle counts, ensure accuracy of stock and, finally, optimise the inventory (determining optimal stock levels and the fast and slow movers in the warehouse in order to optimise stock locations). 
The activities within inventory management are evident in the following quotations:

'Understanding the accuracy of the stock, how to ensure that all the stock has been captured and what are the time lines and all of those things.' (P14, male, senior HR business partner)

'Also inventory optimisation, you know, what's your stock levels, it should be, and your fast movers and slow movers.' (P11, male, divisional director)

The participants then require new graduates to be able to put the stock into the correct locations and then move on to the picking of stock. New graduates must be able to consolidate various orders, correctly pick the necessary goods and then move the picked goods to the cages, ready for distribution. This is illustrated in the following quotations:

'So the idea is to let them free in the warehouse and to let them do the work themselves. So you if you tell a guy, you have to pick 50 lines per hour, then they must understand what picking 50 lines an hour is about.' (P8, male, supply chain solutions manager - translated from Afrikaans)

'Then, from an inventory side of things they also teach you how to, you know, create consolidations on, on SAP and kind of manage the product.' (P5, male, warehouse coordinator)

The remaining participants do not expect new graduates to physically take part in the various warehousing activities. However, they required them to have a comprehensive understanding of the different activities and process flows in the warehouse. This knowledge is critical for this firm, as they expect new graduates to design supply chain solutions for different customers. The following quote demonstrates the importance of this knowledge:

'So those types of guys must be in a position to bring together all the different elements.' (P4, male, supply chain specialist - translated from Afrikaans)

In contrast to the other 11 participants, $\mathrm{P} 6$ stated that $\mathrm{O} 4$ does not provide warehousing services. They only have crossdock facilities where the graduates are expected to perform both break-bulk and cross-dock activities, as can be seen from the quotation below:

'We, we do have a, so what we have is what we call a break-bulk centre. So, everything will come in and then we'll split it.' (P6, male, Western Cape regional manager)
The last warehousing skill, as mentioned by P11 and P13, includes new graduates designing the layout of the warehouse, as can be seen in the following quotation by P11:

'We gave them a bit of an exercise and said, you know, we've got this new thing that we want to do and we need to look at the layouts and so on.' (P11, male, divisional director)

\section{Transportation management}

Concerning transportation management, the skills expected from the new graduates by the 3PL industry are presented in Table 6.

Following the flow of activities, seven participants required new graduates to take part in loading the picked goods into the vehicle and to optimise the loads to reduce the cost of transportation. The following quotation serves as an example:

'Then, from an out, outbound perspective as well, they teach you how to load the trucks and, when I say that's system wise.' (P5, male, warehouse director)

An important skill mentioned by eight participants is that a new graduate should be able to plan the routes for various vehicles and schedule when these vehicles must leave for deliveries. This is done by using computer software, and thus graduates must be technologically proficient to enable them to optimise the chosen routes for deliveries. Route planning and the use of technology during this activity are shown by the following quotation:

'We've got, you know, systems that are set up and that they do route planning and scheduling. So you could use a graduate as a planner or as one of the planners within a team to give that extra exposure to the graduate and, get that extra resource capability.' (P10, male, business development and sales executive)

Three participants required graduates to take part and gain experience in physically delivering the stock to different clients, whereas five participants only required new graduates to be able to track the vehicles and use the applicable technology. These expectations are illustrated in the following quotations:

'They will actually take their guys, they will get on a truck, they will go do a delivery.' (P11, male, divisional director)

'So we've got a whole nerve centre in the Cape and a whole tracking department here that constantly checks.' (P9, male, operations manager)

TABLE 6: The industry's expectations concerning transportation skills.

\begin{tabular}{|c|c|c|c|c|c|c|c|c|c|c|c|c|c|}
\hline \multirow[t]{2}{*}{ Skills } & \multicolumn{12}{|c|}{ Participants } & \multirow[t]{2}{*}{ Total } \\
\hline & P1, P2, P3 & P4 & P5 & P6 & P7 & P8 & P9 & P10 & P11 & P13 & P14 & P15 & \\
\hline Route planning and scheduling & $\mathrm{x}$ & - & - & $x$ & $x$ & $x$ & - & $\mathrm{x}$ & $\mathrm{x}$ & $\mathrm{x}$ & $\mathrm{x}$ & - & 8 \\
\hline Vehicle loading & $x$ & - & $x$ & $x$ & - & $x$ & $x$ & - & - & - & $x$ & $x$ & 7 \\
\hline Vehicle tracking & - & - & - & $x$ & $x$ & - & $x$ & - & $x$ & - & $x$ & - & 5 \\
\hline Route optimisation & - & - & $x$ & $x$ & - & - & - & - & $x$ & $x$ & - & - & 4 \\
\hline Delivering & - & - & - & - & - & - & - & - & $x$ & - & $x$ & $x$ & 3 \\
\hline Freight forwarding & - & - & - & - & $x$ & $\mathrm{x}$ & - & - & $x$ & - & - & - & 3 \\
\hline Expediting & - & $x$ & - & - & - & - & $x$ & - & - & - & - & - & 2 \\
\hline Fleet management & - & - & - & $\mathrm{x}$ & - & - & $\mathrm{x}$ & - & - & - & - & - & 2 \\
\hline
\end{tabular}

$P$, participant; $X$, indicator. 
The last three and least mentioned transportation skills expected from new graduates include fleet management, freight forwarding and expediting. This requires graduates to firstly monitor the vehicles and ensure they are in working order and are serviced regularly. Participants also require graduates to gain exposure to and perform freight forwarding activities. This occurs only when firms import goods and graduates take part in coordinating importation activities. Lastly, graduates must be able to expedite orders when there are delays during the delivery of goods.

\section{General supply chain management skills}

The general supply chain management skills identified by the participants are listed in Table 7.

For the participants, it is important for new graduates to take part in and gain an understanding of the different warehousing and transport activities in order to map out each of the processes' flows. This experience and skills allow new graduates to analyse each of the mapped processes, find ways to improve activities and the subsequent process, and to develop complete supply chain solutions, as can be seen in the following quotations:

'And obviously the operations, process flow, optimisation, ask them to map out certain processes.' (P6, male, Western Cape regional manager)
'So they came up with process improvements.' (P11, male, divisional director)

'So your data analysis and then from there, when a customer approaches us, it is to actually build a, call it a supply chain solution for them.' (P13, male, business development director)

The most important skill expected from new graduates is being proficient with technologies. Graduates must be able to work with various systems (such as warehouse and transportation management systems), use technology to plan and schedule routes, and use new and different technologies to improve the processes, ultimately improving 3PL performance. This can be seen in the following quotations:

'So the expectation would always be that the graduate would bring the technological side to the business.' (P7, male, supply chain solutions manager - translated from Afrikaans)

'Would then go, okay, here is where this operations is lacking certain technologies that would assist this process and things like that.' (P5, warehouse coordinator)

Graduates should have advanced skill and proficiency in Microsoft Excel, as is explained in the quotation:

'So, it's just a bit of a thing that Excel is still a big tool.' (P13, male, business development director)

TABLE 7: The industry's expectation concerning general supply chain management skills.

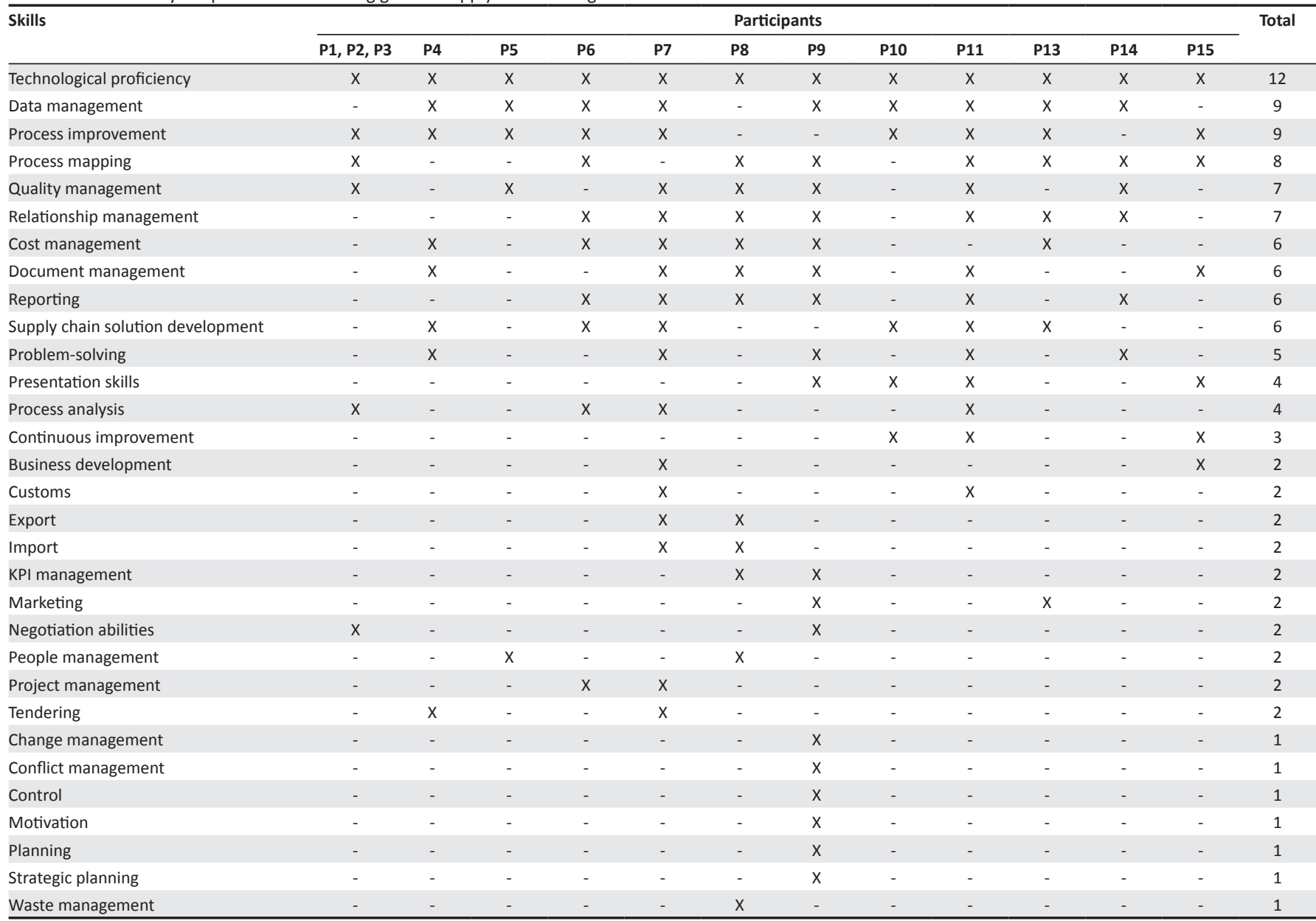

$\mathrm{P}$, participant; $\mathrm{X}$, indicator; $\mathrm{KPI}$, key performance indicator. 
Being proficient in technology will also help graduates in managing data, as nine participants list this as an important skill. The following quotation illustrates that graduates must be able to collect, analyse and then convert the insights gained into meaningful business decisions:

'We expect our grads to be able to capture date accurately, and interpret the data.' (P4, male, supply chain specialist - translated from Afrikaans)

An important part of data management is the skill of graduates being able to report on the insights gained and be able to present information when necessary.

New graduates must also manage quality throughout the supply chain, which includes ensuring the accuracy of received stock, ensuring picking quality (picking the correct quantity and type of stock), delivering the correct quality of products (ensuring that no damaged goods get delivered) and ensuring the accuracy of documents used throughout the supply chain. The following quotations are evidence of these skills:

'If you follow the ISO principles, then you have your quality checks that ensure your business runs smoothly.' (P9, male, operations manager - translated from Afrikaans)

'But obviously, because we've got a number of functions, we do have what we call checking as well after picking.' (P14, male, senior HR business partner)

Comparing all the above-mentioned skills (warehouse management, transportation management and general skills) with the skills identified in Table 3, it can be stated that the findings concur with the existing literature with regard to what is expected from supply chain graduates in other countries around the world (Curkovic \& Fernandez 2016:699; Elzarka \& El-Nakib 2014:3; Sohal 2013:430). This suggests that the South African 3PL industry is comparable to other, worldwide industries with respect to their expectations of new graduates. However, what differs from all the existing literature is the strong emphasis placed on graduates using technology to improve various process flows, which is a significant addition to the current body of knowledge.

However, as stated by nine participants, new graduates are currently not sufficiently equipped to meet the aforementioned skills expectations, especially the missing practical skills element. The lack of adequate skills thus led to the nine firms providing training in the aforementioned skills to newly appointed graduates. The lack of skills identified is illustrated in the following three quotations:

'Do universities prepare you for the life in the industry, absolutely not. I think they miss the point completely concerning the practical, operational experience.' (P4, male, supply chain specialist - translated from Afrikaans)

'As far as we see, the graduates arrive here as a blank slate.' (P7, male, supply chain solutions manager)

'The skill side is always what we then want to build, which is why we take them through this rigorous programme.' (P14, male, senior HR business partner)

\section{Findings related to personal attributes}

The personal attributes that 3PLs look for in new graduates are listed in Table 8.

The personal attributes mentioned in Table 8 confirm the current literature, as discussed in Table 3 (Curkovic \& Fernandez 2016:699; Elzarka \& El-Nakib 2014:3; Sohal 2013:430), except for graduates possessing the right mentality (being willing to start with basic work activities, not having their own office and receiving a large initial salary), which is an addition to academic knowledge. The ability of new graduates to communicate effectively is clearly the most

TABLE 8: The industry's expectation concerning personal attributes needed.

\begin{tabular}{|c|c|c|c|c|c|c|c|c|c|c|c|c|c|}
\hline \multirow[t]{2}{*}{ Personal attributes } & \multicolumn{12}{|c|}{ Participants } & \multirow[t]{2}{*}{ Total } \\
\hline & P1, P2, P3 & P4 & P5 & P6 & P7 & P8 & P9 & P10 & P11 & P13 & P14 & P15 & \\
\hline Communication & $x$ & $x$ & $x$ & - & $x$ & $x$ & $x$ & $x$ & - & - & - & $x$ & 8 \\
\hline Hard-working & - & $x$ & $x$ & - & - & $x$ & $x$ & - & - & - & $x$ & $x$ & 6 \\
\hline Right mentality & $x$ & - & $x$ & - & $x$ & $x$ & - & - & - & - & $x$ & $x$ & 6 \\
\hline Analytical ability & - & - & $x$ & - & - & - & $x$ & - & $x$ & $x$ & - & - & 4 \\
\hline Continuous learning & $x$ & - & $x$ & $x$ & - & - & - & - & - & - & $x$ & - & 4 \\
\hline Innovative & - & $x$ & $x$ & $x$ & - & - & - & - & - & - & - & $x$ & 4 \\
\hline Integrity & - & $x$ & - & - & - & - & $x$ & - & $x$ & - & - & $x$ & 4 \\
\hline Adaptable & $x$ & - & $x$ & - & - & - & - & - & - & $x$ & - & - & 3 \\
\hline Confidence & - & - & $x$ & - & $x$ & - & - & - & $x$ & - & - & - & 3 \\
\hline Critical thinking & - & - & - & - & $x$ & - & - & $x$ & - & - & - & $x$ & 3 \\
\hline Culture fit & - & $x$ & - & - & - & - & - & - & $x$ & - & $x$ & - & 3 \\
\hline Passion & $x$ & - & - & - & - & - & - & - & $x$ & - & $x$ & - & 3 \\
\hline Self-management & $x$ & - & - & $x$ & - & - & - & - & - & - & - & $\mathrm{x}$ & 3 \\
\hline Extrovert & $x$ & - & - & - & - & - & $x$ & - & - & - & - & - & 2 \\
\hline Leadership abilities & - & - & $x$ & $x$ & - & - & - & - & - & - & - & - & 2 \\
\hline Respect & - & - & - & - & - & - & $x$ & - & - & - & - & $x$ & 2 \\
\hline Teamwork & - & - & - & - & - & - & $x$ & - & $\mathrm{X}$ & - & - & - & 2 \\
\hline Diversity management & - & - & - & - & - & - & $x$ & - & - & - & - & - & 1 \\
\hline Trust & - & - & - & - & - & - & $x$ & - & - & - & - & - & 1 \\
\hline
\end{tabular}

P, participant; $X$, indicator. 
important attribute for participants. Effective communication must take place in writing and orally, and graduates must have the ability to communicate with people of various ranks within and outside the 3PL. This can be seen in the following quotation:

'You must be able to handle it, you must know how to speak to people.' (P8, male, supply chain solutions manager - translated from Afrikaans)

'Where do we feel that they are lacking at that stage, at those early stages, is the ability to conduct a business conversation with the client.' (P10, male, business development and sales executives)

The exception to the current literature, graduates possessing the right mentality, requires new graduates to have a realistic understanding of what the 3PL industry will require of them (Curkovic \& Fernandez 2016:699; Elzarka \& El-Nakib 2014:3; Sohal 2013:430). This includes new graduates being hardworking, working long hours, not sitting in the office, working in the warehouse, wearing safety gear and not receiving a large salary at the beginning of their career. The expected mentality of new graduates is illustrated in the following quotations:

'The thing is that the guys must have the patience to work for and run around, doing the basic work.' (P8, male, supply chain solutions manager - translated from Afrikaans)

'From a money perspective, I think, you know, they also walk out ... they've got all these degrees, they're just going to get paid this lump sum of cash every month.' (P5, male, warehouse coordinator)

Graduates must also think in a very critical and analytical manner. This attribute is very important as it will help graduates to analyse various processes and data, leading to them improving the processes, making better decisions and solving problems that arise. The following quotations illustrate these attributes:

'It's great, it will always be that way, but it is expected that the universities teach guys more critical thinking, problem solving systems.' (P7, male, supply chain solutions manager -translated from Afrikaans)

'You know, kind of having a more analytical mind, mindset is also quite important.' (P5, male, warehouse coordinator)
Other notable attributes mentioned by the participants include graduates wanting to learn continuously, being innovative and creative in solving problems and improving processes, fitting into the company culture, being trustworthy and being able to work with others and in a team.

\section{Findings related to knowledge}

Table 9 presents the knowledge elements that participants stated new graduates must possess.

For participants, it is most important that new graduates have knowledge of the latest technologies available, the different technological systems used throughout the supply chain and a basic understanding of how these systems work. This finding confirms the importance of this knowledge as discussed in the literature review. This knowledge, combined with the technological proficiency as mentioned, is critical for participants, as it will help graduates to improve various processes within the supply chain. The importance of this knowledge is illustrated in the following quotations:

'Because they should have a general idea of what technology is out there and best practice. That is what we do expect of them.' (P15, female, training and development specialist)

'What works, what doesn't work, what options are there or what technology can be used. How that will impact the whole process?' (P7, male, supply chain solutions manager - translated from Afrikaans)

The participants expected that their new graduates should also be knowledgeable about various topics, like an in-depth understanding of supply chain management (the different processes, activities and elements of supply chains), the terminology used (including abbreviations and incoterms) and basic financial knowledge. It is also important that graduates have an understanding of how all the various parts of the business integrate with each other. They must know how decisions, technology and problems in one department of a business impact other departments. The following quotations explain the importance of the various topics:

TABLE 9: The industry's expectation concerning knowledge needed.

\begin{tabular}{|c|c|c|c|c|c|c|c|c|c|c|c|c|c|}
\hline \multirow[t]{2}{*}{ Knowledge } & \multicolumn{12}{|c|}{ Participants } & \multirow[t]{2}{*}{ Total } \\
\hline & P1, P2, P3 & P4 & P5 & P6 & P7 & P8 & P9 & P10 & P11 & P13 & P14 & P15 & \\
\hline Technology & $x$ & $x$ & $\mathrm{x}$ & $x$ & $x$ & $x$ & $x$ & $x$ & $x$ & $x$ & $x$ & $x$ & 12 \\
\hline Comprehensive supply chain knowledge & $x$ & - & $x$ & - & $x$ & - & - & $x$ & $x$ & $x$ & - & $x$ & 7 \\
\hline Financial knowledge & - & $x$ & - & - & $x$ & $x$ & $x$ & - & $x$ & $x$ & - & $x$ & 7 \\
\hline Terminology & - & $x$ & $x$ & $x$ & - & - & $x$ & $x$ & $x$ & - & $x$ & - & 7 \\
\hline Business integration & - & $x$ & $x$ & - & $x$ & - & - & - & - & $x$ & - & $x$ & 5 \\
\hline Business understanding & $x$ & - & $x$ & - & $x$ & - & - & $x$ & - & - & - & $x$ & 5 \\
\hline Equipment & $x$ & - & - & - & - & $x$ & $x$ & - & $x$ & - & $x$ & - & 5 \\
\hline Industry knowledge & - & - & - & $x$ & $x$ & $x$ & $x$ & - & $x$ & - & - & - & 5 \\
\hline Product-specific knowledge & - & $x$ & - & - & $x$ & $x$ & - & - & $x$ & $x$ & - & - & 5 \\
\hline Supply chain integration & - & $x$ & - & - & $x$ & - & - & - & $x$ & $x$ & $x$ & - & 5 \\
\hline Laws and regulations & - & $x$ & - & - & $x$ & - & $x$ & - & $x$ & - & - & - & 4 \\
\hline SHEQ & $x$ & - & - & - & - & - & $x$ & $x$ & - & - & - & - & 3 \\
\hline Labour legislation & - & - & - & - & - & $\mathrm{x}$ & $\mathrm{x}$ & - & - & - & - & - & 2 \\
\hline
\end{tabular}

P, participant; $X$, indicator; SHEQ, safety, health, environment and quality. 
'So good understanding of the total supply chain and the principles, fundamentals, at least, the theory.' (P13, male, business development director)

'I think a few guys get one or two weeks in finance to understand what is happening with the whole finance side. How everything impacts each other.' (P15, female, training and development specialist)

Lastly, and differing from the current literature, the participants required new graduates to have a thorough understanding of the products handled by their organisation (Curkovic \& Fernandez 2016:699; Elzarka \& El-Nakib 2014:3; Sohal 2013:430). Graduates must know what the specific requirements are of the product, as well as specific legislation and regulations impacting the supply chain activities of the products. This is evident in the following quotation:

'So health care products need to be good temperature controlled, some of them need to be refrigerated, all those type of things.' (P11, male, divisional director)

\section{Conclusion}

\section{Summary of findings and theoretical implications}

The aim of this study was to determine what 3PLs expect from new graduates with a bachelor's degree in supply chain management or related fields concerning their skills, personal attributes and knowledge. Concerning the 3PL industry's skills expectations, the participants expected new graduates to be able to perform various activities throughout the supply chain, such as warehousing and transport activities. Eleven participants required graduates to actively take part in different operational activities, such as receiving of goods, managing inventory, picking and loading goods into the vehicles and, consequently, planning and scheduling transportation and delivery of the goods. Furthermore, a strong emphasis is placed on graduates improving the different processes in the supply chain, mainly through use of technology.

With regard to the expectations of personal attributes, the 3PL industry expects new graduates to be innovative and creative in doing their work and solving problems. Thinking analytically, wanting to learn continuously and having the ability to communicate well with others are also important attributes. In addition, the participants stressed the importance of new graduates fitting into the culture of the firms and possessing the right mentality towards their position and industry.

Lastly, the knowledge expected from new graduates includes possessing knowledge of new and available technology, the current news and developments within the industry, supply chain-specific knowledge, the financial aspect of supply chains, the integration of various business elements, such as how decisions made throughout the supply chain impact other departments (e.g. the financial implications of decisions) and knowledge of the specific products handled and the subsequent equipment use, which are crucial for new graduates to be successful within the 3PL industry. The participants expressed that new graduates are adequately equipped with the knowledge expected. However, a misalignment exists between the skills expected in the 3PL industry and those delivered by universities.

It can thus be concluded that the findings of this study contribute to current academic knowledge, addressing the specific knowledge gap of skills, personal attributes and knowledge expectations of the South African 3PL industry from new graduates with a bachelor's degree in supply chain management and any related fields. The findings confirm the current knowledge concerning what is expected of these new graduates within an international context. The skill to use technology to improve various processes, new graduates possessing the right mentality and fitting into the specific firm's culture, and lastly possessing product-specific knowledge are newly identified industry expectations.

\section{Managerial implications}

The managerial implication of this study is focused on providing tertiary academic institutions with the necessary knowledge, to enable them to address the misalignment between the required and provided skills. Using the findings of this study, tertiary institutions can critically analyse the current curricula offered, comparing what skills are currently being taught and what the industry expects from new graduates. This analysis can lead to these institutions revising the curriculum offered, finding new ways in which they can provide education to new graduates which will equip them with the practical skills element required. Providing graduates with more exposure and experiences in real-life supply chain settings is important. As stated by the participants, universities can include a practical element into the various degree offerings, requiring graduates to work within a firm for a certain period of time in the form of an internship. 3PLs can also develop new or align existing graduate development programmes to provide new graduates with the required opportunities and exposure to gain the needed practical experience. This can enable new graduates to gain experience and become more proficient in the firms in less time. Ultimately, this could lead to better equipped graduates entering the industry, becoming active and contributing employees in a shorter time.

\section{Limitations and directions for future research}

The study focused solely on the 3PL industry and did not consider the expectations of various other industries, such as manufacturing, fast-moving consumer goods and the automotive industry. The study should thus be replicated in various other industries in order to gain a better and more representative sample and understanding of what is expected from new graduates in the South African supply chain industry. A second limitation is that the study focused only on the industry's expectation and not that of the other key role players, namely the graduates. Future studies should thus focus on obtaining the perspectives and expectations of 
new graduates. These perspectives may assist South African tertiary institutions with insights into the work readiness of supply chain management graduates. Possessing knowledge of the perspectives of the tertiary institutions, the industry's expectations and graduates who might have experienced a form of mismatch will allow for a better understanding of the causes of this mismatch. The study can also be replicated in various disciplines outside of supply chain management. Determining what different industries expect from their respective graduates (e.g. engineering graduates or marketing graduates) will allow for tertiary institutions to align their curricula with what the respective industries require. Better alignment can ultimately lead to a better equipped and performing workforce.

\section{Acknowledgements Competing interests}

The authors declare that they have no financial or personal relationships that may have inappropriately influenced them in writing this article.

\section{Authors' contributions}

This article is based on the MPhil dissertation of M.A. who was the main researcher. W.N. assisted as a supervisor with the conceptualisation, literature review, research instruments and review of the draft manuscript. T.K. provided methodological and technical guidance.

\section{References}

Aida, B., Norailis, W. \& Rozaini, R., 2015, 'Critical success factor of graduate employability programs', Journal of Economics, Business and Management 3(8), 767-771. https://doi.org/10.7763/JOEBM.2015.V3.283

Akman, G. \& Baynal, K., 2014, 'Logistics service provider selection through an integrated fuzzy multicriteria decision making approach', Journal of Industria Engineering 2014, 1-16, viewed 19 November 2017, from https://doi org/10.1155/2014/794918

APICS, 2014, Supply chain manager competency model, viewed 24 February 2017 from http://www.apics.org/docs/default-source/careers-competency-models/ supply-chain-manager-competency-model.pdf?sfvrsn $=6$

Barloworld Logistics, 2016a, Skills and education, viewed 15 May 2017 from http:// www.barloworld-logistics.com/wp-content/uploads/2016/11/BarloworldLogistics-youth-foresightreport-Nov-2016.pdf

Barloworld Logistics, 2016b, Supply chain foresight navigating smart, viewed 27 February 2017, from http://www.barloworld-logistics.com/wp-content/uploads/ 2016/02/supplychainforesight-2016-report.pdf

Bloem, N. \& Bean, W.L., 2015, 'The application of outsourcing decision-making methods in a logistics context in South Africa', Journal of Transport and Supply Chain Management 9(1), 1-14. https://doi.org/10.4102/jtscm.v9i1.168

Cevik Onar, S., Aktas, E., Ilker Topcu, Y. \& Doran, D., 2013, 'An analysis of supply chain related graduate programmes in Europe', Supply Chain Management: An International Journal 18(4), 398-412. https://doi.org/10.1108/SCM-06-2012-0209

Chetty, Y., 2012, 'Graduateness and employability within the higher education environment', in M. Coetzee, J. Botha, N. Eccles, H. Nienaber \& N. Holtzhausen (eds.), Developing student graduateness and employability, pp. 5-24, Knowres Publishing, Randburg.

Christine, J. \& Ozlem, B., 2016, 'The growing scale and scope of the supply chain: A reflection on supply chain graduate skills', Supply Chain Management: An International Journal 21(5), 610-626. https://doi.org/10.1108/SCM-02-2016-0059

Cilliers, W.W., 2015, The development of an integrated supply chain competency model, Stellenbosch University, Stellenbosch viewed 04 November 2017, from model, Stellenbosch University, Stellenbosch vis.
$\mathrm{http}: / /$ scholar.sun.ac.za/handle/10019.1/97887

Clarke, V. \& Braun, V., 2013, 'Teaching thematic analysis: Overcoming challenges and developing strategies for effective learning', The Psychologist 26(2), 120-123.

Cooper, S. \& Endacott, R., 2007, 'Generic qualitative research: A design for qualitative research in emergency care?', Emergency Medicine Journal 24(12), 816-819. https://doi.org/10.1136/emj.2007.050641

Creswell, J.W., 2012, Education research: Planning, conducting and evaluating quantitative and qualitative research, 4 th edn., Pearson, Boston, MA.
Curkovic, S. \& Fernandez, N., 2016, 'Closing the gap in undergraduate supply chain education through live experiential learning' American Journal of Industrial and Business Management 6(6), 697-708. https://doi.org/10.4236/ajibm.2016. 66064

Elzarka, S. \& El-Nakib, I., 2014, 'Skills requirements for entry-level logisticians: An empirical study of academics and practitioners perception in Egypt', paper presented at the 19th Logistics Research Network Conference, University of Huddersfield, UK, 3-5 September, pp. 1-9, viewed 11 March 2017, from https://www.researchgate. 3-5 September, pp. 1-9, viewed 11 March 2017, from https://www.researchgate.
net/profile/Islam El-Nakib/publication/280730321 SKILLS REQUIREMENTS_FOR net/profile/Islam_EI-Nakib/publication/280730321_SKILLS_REQUIREMENTS_FOR_ ENTRY_LEVEL_LOGGISTICIANS_AN_EMPIRICAL_STUUDY_OF_ACADEMICS_AND
PRACTITIONERS_PERCEPTION_IN_EGYPT/links/55c3681d08aebc967dfOf2ad.pdf

Francis, J.J., Johnston, M., Robertson, C., Glidewell, L., Entwistle, V., Eccles, M.P. et al., 2010, 'What is an adequate sample size? Operationalising data saturation for theory-based interview studies', Psychology \& Health 25(10), 1229-1245. https:// doi.org/10.1080/08870440903194015

Fraser, J., 2013, 'A gap analysis of employee training needs in supply chain management', DCom thesis, Dept of Business Management, University of Pretoria.

Hamilton, R.J., 2014, 'Using skype to conduct interviews for psychosocial research', CIN: Computers, Informatics, Nursing 32(8), 353-358. https://doi.org/10.1097/ CIN: Computers, Informatic
CIN.0000000000000095

Havenga, J.H., Simpson, Z.P., King, D., De Bod, A. \& Braun, M., 2016, Logistics barometer South Africa 2016, University of Stellenbosch, Stellenbosch, viewed 27 February 2017, from http://www.sun.ac.za/english/faculty/economy/logistics/Documents/ 2017, from http://www.sun.ac.za/english/faculty/economy/logistics/Dod
Logistics\%20Barometer/Logistics\%20Barometer\%202016\%20Report

Heyns, G. \& Luke, R., 2012, 'Skills requirements in the supply chain industry in South Africa', Journal of Transport and Supply Chain Management 6(1), 107-125. https://doi.org/10.4102/jtscm.v6i1.34

Hwang, B., Chen, T. \& Lin, J.T., 2016, '3PL selection criteria in integrated circuit manufacturing industry in Taiwan', Supply Chain Management: An International Journal 21(1), 103-124. https://doi.org/10.1108/SCM-03-2014-0089

Jasti, N.V.K. \& Kodali, R., 2014, 'A literature review of empirical research methodology in lean manufacturing', International Journal of Operations \& Production Management 34(8), 1080-1122. https://doi.org/10.1108/IJOPM-04-2012-0169

Ju, S., Zhang, D. \& Pacha, J., 2011, 'Employability skills valued by employers as important for entry-level employees with and without disabilities', Career Development and Transition for Exceptional Individuals 35(1), 29-38. https://doi. org/10.1177/0885728811419167

Jusoh, M., Simun, M. \& Choy Chong, S., 2011, 'Expectation gaps, job satisfaction, and organizational commitment of fresh graduates', Education + Training 53(6), 515-530. https://doi.org/10.1108/00400911111159476

Karrapan, C., Sishange, M., Swanepoel, E. \& Kilbourn, P.J., 2017, 'Benchmarking criteria for evaluating third-party logistics providers in South Africa', Journal of Transport and Supply Chain Management 11(1), 1-10. https://doi.org/10.4102/ jtscm.v11i0.305

Lambert, V.A. \& Lambert, C.E., 2012, 'Qualitative descriptive research: An acceptable design', Pacific Rim International Journal of Nursing Research 16(4), 255-256.

Langley, C.J., 2016, The state of logistics outsourcing, viewed 03 October 2017, from https://www.kornferry.com/media/sidebar_downloads/2016_3PL_Study.pdf

Langley, C.J., 2017, The state of logistics outsourcing, viewed 03 October 2017, from http://www.sipotra.it/wp-content/uploads/2017/06/2017-Third-Party-LogisticsStudy-The-State-of-Logistics-Outsourcing.pdf

Lowden, K., Hall, S., Elliot, D. \& Lewin, J., 2011, Employers' perceptions of the employability skills of new graduates, Edge foundation, London.

Meyer, A., Niemann, W. \& Kotzé, T., 2017, 'Exploring the dark side of interpersonal relationships between buyers and suppliers of logistics services', Acta Commercil 17, 1-12. https://doi.org/10.4102/ac.v17i1.437

Modisaotsile, B.M., 2012, 'The failing standard of basic education in South Africa', Policy Brief 72, 1-7.

Murphy, P.R. \& Poist, R.F., 2006, 'Skill requirements of contemporary senior- and entry-level logistics managers: A comparative analysis', Transportation Journal 45(3), 46-60.

Nzimande, B.E., 2016, List of occupations in high demand: 2015, viewed 10 March 2017, from http://www.dhet.gov.za/Gazette/Government $\% 20$ Gazette $\% 20$ No $\% 20$ $39604, \% 2019 \% 20$ January $\% 202016 . \% 20$ List $\% 20$ of $\% 20$ Occupations $\% 20$ in $\% 20$ High\%20Demand\%202015.pdf

Oxford, 2017, English Oxford living dictionaries, viewed 01 November 2017, from https://en.oxforddictionaries.com

Palinkas, L.A., Horwitz, S.M., Green, C.A., Wisdom, J.P., Duan, N. \& Hoagwood, K., 2015, 'Purposeful sampling for qualitative data collection and analysis in mixed method implementation research', Administration and Policy in Mental Health and Mental Health Services Research 42(5), 533-544. https://doi.org/10.1007/ s10488-013-0528-y

Plano Clark, V.L. \& Creswell, J.W., 2015, Understanding research: A consumer's guide, 2nd edn., Pearson, Upper Saddle River, NJ.

Polit, D.F. \& Beck, C.T., 2012, Nursing research: Generating and assessing evidence for nursing practice, 9th edn., Wolters Kluwer Health | Lippincott Williams \& Wilkins, Philadelphia, PA

Reddy, V., Bhorat, H., Powell, M., Visser, M. \& Arends, A., 2016, Skills supply and demand in South Africa, viewed 14 May 2017, from http://www.hsrc.ac.za/ uploads/pageContent/7429/LMIP_SkillsSupplyandDemand_Sept2016.pdf

Shenton, A.K., 2004, 'Strategies for ensuring trustworthiness in qualitative research projects', Education for information 22(2), 63-75. https://doi.org/10.3233/EFI2004-22201 
Sohal, A.S., 2013, 'Developing competencies of supply chain professionals in Australia: Collaboration between businesses, universities and industry associations', Supply Chain Management: An International Journal 18(4), 429-439.

TETA, 2017, Scarce and critical skills list, viewed 21 June 2017, from http://www.teta. org.za/Documents/ANNEXURE $\% 201 \% 20$ TETA $\% 202016 \% 2017 \% 20$ Scarce $^{2} \% 20$ and $\% 20$ Critical $\% 20$ skills $\% 20$ List.pdf

Vaismoradi, M., Turunen, H. \& Bondas, T., 2013, 'Content analysis and thematic analysis: Implications for conducting a qualitative descriptive study', Nursing \& Health Sciences 15(3), 398-405. https://doi.org/10.1111/nhs.12048
Van Broekhuizen, H., 2016, Graduate unemployment and higher education institutions in South Africa, Stellenbosch University, Stellenbosch, viewed 10 March 2017 from www.ekon.sun.ac.za/wpapers/2016/wp082016/wp-08-2016.pdf

Vitasek, K., 2013, Supply chain management terms and glossary, CSCMP, Not known viewed 03 November 2017, from http://cscmp.org/CSCMP/Educate/SCM Definitions and Glossary of Terms/CSCMP/Educate/SCM Definitions and Glossary of_Terms.aspx?hkey=60879588-f65f-4ab5-8c4b-6878 815ef921-

Vokurka, R.J., 2011, 'Supply chain manager competencies', SAM Advanced Management Journal 76(2), 23-37. 